\title{
Volcanic-hosted Be-(Li-F-REE-U) deposits: Insights into source rocks, geochemical signatures, and macro- to-microscale concentration processes
}

\author{
NORA FOLEY $^{* 1}$ ROBERT AYUSO ${ }^{1}$ AND JORGE VAZQUEZ ${ }^{2}$ \\ ${ }^{1}$ U.S Geol. Surv., Reston, VA, USA, (*correspondence: \\ nfoley@usgs.gov, rayuso@usgs.gov) \\ ${ }^{2}$ U.S Geol. Surv., Menlo Park, CA, USA \\ (jvazquez@usgs.gov)
}

Among the most important rare-metals in the modern world is beryllium (Be), which is used to produce complex alloys and ceramics critical for telecommunication, aerospace, medical, and defense industries. Global $\mathrm{Be}$ supplies are primarily obtained from bertrandite $\left(\mathrm{Be}_{4} \mathrm{Si}_{2} \mathrm{O}_{7}(\mathrm{OH})_{2}\right)$ mined from a single volcanic-hosted Be-(Li-F-REE-U) deposit at Spor Mountain, Utah, USA. The ores occur in lithic-rich, phreato-magmatic base-surge deposits near the ring fracture of an Oligocene caldera. The ore bodies are part of a package of rare-metal-rich rhyolite lava flows, pyroclastic deposits, and fluorite-bearing pipes. New age and rock chemistry data [1] indicate that at $\sim 25.6$ Ma highly evolved, trachytic to rhyolitic magmas erupted to form a basal vitric tuff and an upper topaz-bearing rhyolite. $\mathrm{Pb}-\mathrm{Nd}-\mathrm{Sr}$ isotope data, trace elements, and mineral phase relationships map the flux of Be, $\mathrm{Li}, \mathrm{F}, \mathrm{REE}$, and $\mathrm{U}$ in the magmatic-to-hydrothermal system and reveal the role of fluid-rock interactions and recrystallization processes in concentrating the metals. Geochemical models indicate high-grade ore formed under pH-buffered conditions $\left(\sim 100\right.$ to $\left.<250^{\circ} \mathrm{C}\right)$, when F-rich fluids leached metals from glass-rich tuff, reacted with carbonate xenoliths in tuff, and concentrated $\mathrm{Be}$ and other rare metals in complexly layered nodules of Mn-oxide, Li-smectite, calcite, fluorite, opal, and bertrandite ( $<1-10 \%)$. U-Pb age dating of individual opal layers establishes timescales of opal growth and high-grade ore formation (in-situ age and 29-element analysis by SHRIMP-RG ion microprobe). The results show an almost continous record of opal deposition, from $~ 25.6$ Ma to $\sim 2 \mathrm{Ma}$. The major flux of Be, F, REE, and Li occurred from $\sim 16 \mathrm{Ma}$ to $10 \mathrm{Ma}$; $\mathrm{U}$ flux peaked at $\sim 6$ to $5 \mathrm{Ma}$. Fluidrock interaction and recrystallization had limited effect on other rare elements in tuff and rhyolite. Other Be occurrences in Utah, Nevada, New Mexico, and Texas highlight the economic potential for additional resources of volcanicrelated $\mathrm{Be}$ and co-product Li-F-REE in the western U.S.

[1] Ayuso et al., 2020, J. Geochem. Explor. 109 1-22. 